KS. ARKADIUSZ DOMASZK SDB

Wydział Prawa Kanonicznego

Uniwersytetu Kardynała Stefana Wyszyńskiego w Warszawie

\title{
KATOLICKA TELEWIZJA INTERNETOWA W MYŚLI PRAWNO-KANONICZNEJ KOŚCIOŁA
}

Treść: Wstęp. - 1. Prawo kanoniczne odnoszące się do problematyki telewizyjnej. - 2. Telewizja katolicka w Polsce. - 3. Internetowa telewizja katolicka w Polsce. - Wnioski.

\section{Wstęp}

Współczesna telewizja jest dostępna także w łączności internetowej. Coraz więcej stacji telewizyjnych nadaje sygnał w określonej częstotliwości fal, a jednocześnie emituje wybrane programy, albo całą tzw. „ramówkę” w Internecie. Wraz z klasyczną już formą telewizji rozwijają się stacje telewizyjne, operujące tylko w tzw. cyberprzestrzeni.

W opracowaniu po pierwsze zostaną wskazane normy prawa kanonicznego odnoszące się do problematyki telewizyjnej, zwłaszcza do programów i stacji katolickich. Następny punkt pracy zawierać będzie zarys katolickiej obecności w polskich stacjach telewizyjnych. Ostatnia część pracy będzie prezentować telewizyjną obecność różnych podmiotów katolickich w Internecie. Celem opracowania będzie rozważenie pytania: czy kościelne normy prawne należy zastosować do telewizyjnej obecności katolickiej w wersji elektronicznej (internetowej)? Czy normy aktualnego prawa kanonicznego można odnieść do współczesnej sytuacji mediów elektronicznych? 


\section{Prawo kanoniczne odnoszące się do problematyki telewizyjnej}

Nauczanie Magisterium Kościoła na temat środków komunikacji odzwierciedlają normy prawa kanonicznego. Przede wszystkim są one zebrane w III księdze Kodeksu Prawa Kanonicznego z 1983 r., która zawiera osobny tytuł poświęcony środkom społecznego przekazu, a zwłaszcza publikacjom książkowym ${ }^{1}$. Ze względu na podjęty temat pracy, w niniejszym opracowaniu zostaną pominięte normy dotyczące książek.

Jednakże odnajdziemy ogólne sformułowania Kodeksu Prawa Kanonicznego, które zobowiązują pasterzy do aktywnego korzystania ze wszystkich mediów w misji Kościoła, co należy odnieść również do przekazu telewizyjnego. „W wypełnianiu swojej funkcji, pasterze Kościoła, korzystając z prawa przysługującego Kościołowi, powinni posługiwać się środkami społecznego przekazu"2. W prawie kodeksowym docenia się oddziaływanie telewizji oraz potrzebę

${ }^{1}$ Por. L. Chiappetta, Il Codice di diritto canonico. Commento giuridico-pastorale, t. II, Roma 1996, s. 62-72; C. ERRÁzURIZ, Gli strumenti di comunicazione sociale $e$ in specie i libri, w: Gruppo italiano docenti di diritto canonico - La funzione di insegnare della Chiesa, XIX Incontro di studio passo della Mendola - Trento, 29.06-03.07.1992, Milano 1994, s. 97-117; Tenże, Introduction and Commentary, w: Exegetical commentary on the Code of Canon Law, red. A. Marzoa, J. Miras, R. Rodriguez-Ocaña, t. III/1, Chicago 2004, s. 287-331; Kodeks Prawa Kanonicznego. Komentarz, red. P. Majer, Kraków 2011, s. 628-638; A. DomAszk, Środki komunikacji społecznej w nauczaniu Kościoła i misji ewangelizacyjnej, Seminare. Poszukiwania Naukowe, 34 (2013), s. 81-95.

${ }^{2}$ Codex Iuris Canonici, auctoritate Joannis Pauli PP. promulgatus, Kodeks Prawa Kanonicznego. Przekład polski zatwierdzony przez Konferencję Episkopatu, Poznań 1984 (dalej KPK 1983), kan. $822 \$ 1$; por. tamże, kan. $747 \$ 1$, 761. Zagadnienia dotyczące mediów, a powiązane z misją Kościoła znajdują się również poza trzecią księgą Kodeksu z 1983 r. Osobom konsekrowanym zaleca się roztropność w korzystaniu z mediów, por. tamże, kan. 666. W przygotowaniu do małżeństwa chrześcijańskiego można skorzystać ze środków przekazu, por. tamże, kan. 1063 nr 1. Ponadto przestępstwa kanoniczne: bluźnierstwo, naruszenie obyczajów, znieważenie religii lub Kościoła, wywoływanie nienawiści czy pogardy, jeśli są dokonane za pośrednictwem mediów domagają się zastosowania sprawiedliwej kary, por. tamże, kan. 1369. Obowiązki biskupów wobec mediów, por. także KongREGACJA DS. BISKupów, Dyrektorium o pasterskiej posłudze biskupów Apostolorum successores, 22.02.2004, 
stanowienia szczegółowych norm w tym zakresie: „Gdy idzie o przekazywanie nauki chrześcijańskiej przez radio lub telewizję, należy zachować przepisy wydane przez Konferencję Episkopatu”3. Do bardziej konkretnych zadań Konferencji Episkopatu należy określenie zasad występowania duchownych i osób zakonnych w programach telewizyjnych, gdy dotyczy to przedstawiania nauki katolickiej i obyczajów ${ }^{4}$. Taką instrukcję Polska Konferencja Episkopatu opublikowała w 2005 r. ${ }^{5}$

Odpowiedzialność pasterzy za realizację misji Kościoła prowadzi także do nauczania wiernych, że na wszystkich katolikach spoczywa „obowiązek podejmowania współpracy zmierzającej do tego, by użycie środków społecznego przekazu przepoić duchem ludzkim i chrześcijańskim”6. W konsekwencji, Kościół wzywa też

w: Ustrój hierarchiczny Kościoła. Wybór źródeł, red. W. Kacprzyk, M. Sitarz, Lublin 2006, s. 517-711, nr 138-142.

${ }^{3}$ KPK 1983, kan. $772 \$ 2$. Por. T. Vanzetto, Quando il pulpito da cui viene la predica è la radio o la televisione (can. $772 \$ 2$ ), Quaderni di Diritto Ecclesiale 12 (1999), s. 205-217. Przegląd nauczania Magisterium nt. telewizji, por. A. Zwolıński, Kościół o telewizji, Analecta Cracoviensia 34 (2002), s. 287-307.

${ }^{4}$ Por. KPK 1983, kan. $831 \$ 2$. O różnych rozporządzeniach, które wydały poszczególne Konferencje Episkopatu, w kontekście występowania w radiu i telewizji, por. J. T. MARtin de AgAR, Note sul diritto particolare delle Conferenze Episcopali, Ius Ecclesiae 2 (1990), s. 610-612; P. URso, Il ministero della parola divina, predicazione e catechesi (can. 781-792), w: Gruppo italiano docenti di diritto canonico - La funzione di insegnare della Chiesa, dz. cyt., s. 41-42; T. VAnZeTto, Quando il pulpito, dz. cyt., s. 211-215. Wykorzystanie mediów katolickich w poszczególnych krajach, a w tym i działania Konferencji Episkopatów, por. także Media katolickie: szanse i zagrożenia, red. K. Bieliński, Toruń 2010.

${ }^{5}$ Por. Konferencja Episkopatu Polski, Normy dotyczące występowania duchownych i osób zakonnych oraz przekazywania nauki chrześcijańskiej w audycjach radiowych i telewizyjnych, 09.03.2005, Akta Konferencji Episkopatu Polski 10/1 (2005), s. 74-76 (dalej Instrukcja KEP 2005).

${ }^{6}$ KPK 1983, kan. $822 \$ 2$. Odpowiedzialność kierujących komunikacją społeczną oraz poszczególnych autorów przekazu posiada związek z ochroną wiary, por. A. SŁowıкоwsкA, Ochrona przekazu wiary w mediach. Aspekt kanoniczny, w: Media - wartości - prawo, red. R. Sztychmiler, Olsztyn 2008, s. 39-47; J. KRAJCZYŃSKI, Wystąpienia wiernych $w$ mass mediach $w$ sprawach wiary i obyczajów, w: 
do podejmowania konkretnych działań: „wszyscy wierni, w szczególności zaś ci, którzy mają jakiś udział w organizowaniu lub użyciu środków społecznego przekazu, powinni się starać świadczyć pomoc pasterskiej działalności, tak żeby Kościół mógł także poprzez te środki skutecznie wypełniać swoją misję"7.

W praktyce chodzi m.in. o zaangażowanie wiernych świeckich w redagowanie programów katolickich ${ }^{8}$. Podstawą do unormowania katolickich redakcji - w ramach stacji radiowych czy telewizyjnych - są umowy zawierane pomiędzy Konferencją Episkopatu Polski a Polskim Radiem SA i TVP SA, czy innymi prywatnymi stacjami nadawczymi ${ }^{9}$.

Fides, quae de verbo nascitur et nutritur. Nauczycielskie zadanie Kościoła wobec 1050. rocznicy Chrztu Polski, red. J. Krajczyński, A. Domaszk, Płock 2016, s. 110-130; P. MAJER, Wierni wobec wystąpień i publikacji, które atakują religię i dobre obyczaje, w: tamże, s. 131-160; R. KAMIŃsKI, Prawna ochrona środków komunikacji społecznej, Marki 2016.

${ }^{7}$ KPK 1983, kan. 822 \$3; „Wszyscy wierni mają obowiązek i prawo współpracy w tym, aby Boże przepowiadanie zbawienia rozszerzało się coraz bardziej na wszystkich ludzi każdego czasu i całego świata”, tamże, kan. 211. Por. także C. Errázuriz, Introduction and Commentary, dz. cyt., s. 293-297. Niektóre zagadnienia nie zostały ujęte w normach kodeksowych, np. transmisja Mszy św. przez radio i telewizję, więc należy stosować wskazania innych dokumentów, jak choćby instrukcji Communio et progressio. O transmisji Mszy por. A. BACzYński, Nauczanie Kościoła o przekazie Mszy św. w telewizji, w: Msza św. w telewizji, red. W. Przyczyna, Kraków 2006, s. 7-20.

${ }^{8}$ Katolickie środki przekazu „winny spełniać swą funkcję w zgodzie z doktryną Kościoła oraz w jedności z pasterzami, zgodnie z normami prawa kanonicznego", Apostolorum successores, nr 140.

${ }^{9}$ Umowa z Polskim Radiem SA została zawarta 30 sierpnia 1994 r., a umowa z TVP SA 23 czerwca 1994 r., por. T. Rakoczy, Prawo Kościoła Katolickiego do środków społecznego przekazu w Kodeksie Prawa Kanonicznego z 1983 r. i w konkordatach posoborowych, Gniezno 2005, s. 144-148. Obecności programów katolickich nie można sprowadzić do okienka w tzw. ramówce telewizyjnej czy radiowej, chodzi o tworzenie dynamicznej obecności, która pełni rolę ewangelizującą. Ponadto prawnie zagwarantowany dostęp do radia i telewizji niekiedy napotyka na praktyczne utrudnienia, por. K. OŁDAKOwsкi, Media katolickie w publicznych mediach elektronicznych - czyli blaski i cienie katolickiego "getta" w Polskim Radiu i Telewizji Polskiej, w: Media wyznaniowe w Polsce 1989-2004, red. E. Kossewska, 
Niektóre media są wprost katolickimi. Ich katolicka tożsamość wynika z wielu elementów: powołania przez instytucję kościelną, zapisów w statutach i regulaminach, struktur zarządu itd. Na jedną z ważnych cech, które wpływają na ich tożsamość, wskazuje zapis z II Polskiego Synodu Plenarnego: „każde zarejestrowane czasopismo, rozgłośnia radiowa, stacja, winny mieć asystenta kościelnego, ustanowionego przez miejscowego biskupa"10.

$\mathrm{W}$ świecie mass mediów ważną rolę odgrywają różne agencje informacyjne, $\mathrm{w}$ tym wyspecjalizowane $\mathrm{w}$ zbieraniu i przekazywaniu informacji, z określonych dziedzin życia społecznego. Na gruncie informacji religijnej taką instytucją Kościoła w Polsce jest powołana przez Konferencję Episkopatu Polski w 1993 r. Katolicka Agencja Informacyjna (KAI). Agencja wyraźnie zaznaczyła swoją obecność na polskim rynku medialnym, a jej informacje przytaczają m.in. różne stacje telewizyjne. Zazwyczaj jako pierwsza, KAI opracowuje doniesienia religijne z życia Kościoła w Polsce i na świecie, a ponadto promuje nauczanie papieskie i wszelką działalność katolicką w Polsce i na świecie ${ }^{11}$.

Wezwanie, by katolicy przepoili środki komunikacji duchem ludzkim i chrześcijańskim, należy realizować z roztropnością. W tym

J. Adamowski, Warszawa 2004, s. 129-132; P. WiśNiewski, Dostęp Kościoła do radiofonii i telewizji w ustawodawstwie III RP., w: Zadania nauczycielskie Kościoła wobec wyzwań XXI w., red. J. Krukowski, S. Fundowicz, M. Sitarz, Radom 2010, s. 77-95; Tenże, Radiofonia i telewizja narzędzia stużące realizacji misji Kościoła. Prawo i praktyka w Polsce 1989-2008, Lublin 2010, s. 172, 205-206. Por. też A. GoŁęBIowsкa, Prawo Kościoła katolickiego do środków społecznego przekazu w świetle prawa kanonicznego i prawa polskiego, Warszawa 2010; G. ŁĘCICKI, Kościół w eterze. $W$ dwadzieścia lat po upadku komunizmu, w: Media i Kościól. Polityka informacyjna Kościoła, red. M. Przybysz, K. Marcyński, Warszawa 2011, s. 108-117.

${ }^{10}$ Ewangelizacja kultury i środków społecznego przekazu, w: II Polski Synod Plenarny (1991-1999), Poznań 2001, nr 89.

${ }^{11}$ Por. Katolicka Agencja Informacyjna, Biuletyn KAI 48 (07.12.2003), s. 1-8 (w dodatku); M. Przeciszewski, Katolicka Agencja Informacyjna. Podstawowe zasady relacji z mediami, w: Media i Kościół. Polityka informacyjna Kościoła, red. M. Przybysz, K. Marcyński, Warszawa 2011, s. 47-53. Instytucja posiada własną witrynę internetową: www.ekai.pl. 
kontekście prawodawca kościelny zwraca uwagę na niektóre szczególne sytuacje. Jedną z nich jest występowanie wiernych świeckich i duchownych w mediach wrogich względem Kościoła. Choć wprost norma kodeksowa dotyczy publikacji pisanych, to przez analogię należy ją odnosić do innych środków przekazu, więc i do programów telewizyjnych. Wierni mogą publikować czy występować w tego rodzaju mediach jedynie dla słusznej i uzasadnionej przyczyny, natomiast duchowni i członkowie instytutów zakonnych mogą zamieszczać tamże teksty (brać udział) jedynie za zgodą ordynariusza miejsca ${ }^{12}$. W odniesieniu do duchownych i zakonników chodzi o jakąkolwiek „obecność medialną", nie tylko ściśle w zakresie spraw wiary i moralności. Obecność w konkretnym programie lub stacji telewizyjnej osób kojarzonych z nauczaniem kościelnym - a sutanna czy habit takie skojarzenia rodzą - niejako legitymizuje narzędzie komunikacji i jego przekaz.

W tym miejscu należy ponownie przywołać instrukcję o występowaniu duchownych i osób zakonnych w programach radiowych i telewizyjnych z $2005 \mathrm{r}$. Wyżej wskazany problem został następująco ujęty: „wierni świeccy nie powinni brać udziału w programach czy audycjach przynoszących szkodę wierze lub dobrym obyczajom, tendencyjnie antykościelnych i budzących zgorszenie"13.

Ponadto duchowni i członkowie instytutów zakonnych, kiedy wypowiadają się w mediach, powinni być wierni prawdzie i Ewangelii oraz cechować się rzetelną wiedzą, roztropnością i odpowiedzialnością za wypowiadane słowa. A przy braku wymaganej w danej dziedzinie wiedzy, powinni zrezygnować z występowania w mediach, zwłaszcza w kwestiach trudnych czy kontrowersyjnych ${ }^{14}$. Ich wypowiedzi medialne w sprawach nauki katolickiej lub obyczajów łączą się z głoszeniem nauki Chrystusa, więc nie mogą stanowić prezentacji własnych opinii; a obowiązek wierności katolickiej nauce i Magisterium

\footnotetext{
${ }^{12}$ Por. KPK 1983, kan. $831 \S 1$.

${ }^{13}$ Instrukcja KEP 2005, nr 12.

${ }^{14}$ Por. tamże, nr 8.
} 
Kościoła winien respektować zdanie Konferencji Episkopatu w kwestiach, które były przedmiotem jej oficjalnego stanowiska ${ }^{15}$.

Podobne zasady dotyczą odpowiednio pozostałych wiernych świeckich, którzy wypowiadają się w mediach w sprawach nauki katolickiej lub obyczajów. Szczególnie dotyczy to tych osób, których urząd kościelny albo funkcja pełniona w instytucji kościelnej, czy przynależność do stowarzyszeń lub organizacji kościelnych sprawiają, że ich wypowiedzi medialne mogą być odebrane jako angażowanie autorytetu Kościoła ${ }^{16}$.

Z innych wskazań Kościoła katolickiego w Polsce należy przywołać obowiązek uzyskania zgody własnego ordynariusza na stałą współpracę duchownego lub osoby zakonnej ze stacją telewizyjną ${ }^{17}$. Opracowanie listy stałych współpracowników stacji telewizyjnych dokonuje się przez uzgodnienie dokonane pomiędzy dyrektorami stacji a odpowiednim biskupem ${ }^{18}$. Jednorazowe lub okazjonalne wystąpienie w mediach osoby duchownej lub zakonnika nie wymaga zgody ordynariusza lub przełożonego, choć domaga się wierności nauczaniu Kościoła. Zadaniem biskupa diecezjalnego jest ponadto wyznaczenie koordynatora czy pełnomocnika, który we współpracy z mediami będzie służył pomocą i radą w dziedzinie środków społecznego przekazu ${ }^{19}$; ten sam lub inny kapłan będzie sprawował opiekę duszpasterską nad pracownikami mediów ${ }^{20}$. Szczególną starannością należy objąć transmisje celebracji liturgicznych, odpowiednio przygotowane w znaczeniu technicznym i komentatorskim; transmitować należy na bieżąco, w czasie realnym ${ }^{21}$. Ponadto duchowni oraz za-

\footnotetext{
${ }^{15}$ Por. tamże, nr 9.

${ }^{16}$ Por. tamże, nr 10.

${ }^{17}$ Por. tamże, nr 13.

${ }^{18}$ Por. tamże, nr 14.

${ }^{19} \mathrm{O}$ ile zadania pełnomocnika lub koordynatora dotyczą tylko pomocy w odniesieniu do mediów, nie zaś funkcji duszpasterskich, można wyznaczyć osobę świecką, por. KPK 1983, kan. 228.

${ }^{20}$ Por. Instrukcja KEP 2005, nr 16.

${ }^{21}$ Por. tamże, nr 17-18. Por. także Wskazania Komisji Episkopatu Polski ds. Liturgii i Duszpasterstwa Liturgicznego dotyczące fotografowania i filmowania podczas
} 
konnicy w programach telewizyjnych powinni występować w stroju duchownym lub własnym habicie ${ }^{22}$. Obowiązują ich normy prawa powszechnego (kan. 762-772), w razie ich naruszenia ordynariusz powinien upomnieć osobę duchowną lub zakonnika oraz zobowiązać do naprawienia szkody (sprostowanie lub odwołanie błędnej czy krzywdzącej wypowiedzi), a w szczególnych przypadkach zabronić występowania w mediach lub zastosować inne sankcje karne ${ }^{23}$.

\section{Telewizja katolicka w Polsce}

$\mathrm{Na}$ świecie istnieją liczne katolickie stacje telewizyjne. Wśród przykładów wymienić można: amerykańskie EWTN i Catholic TV, brazylijskie TV Seculo 21 i Canção Nova, włoskie Telepace i SAT 2000, watykańskie CTV, francuskie KTO, słowackie TV LUX oraz wiele innych ${ }^{24}$. Na tym tle polska sytuacja wygląda skromniej. Przemiany ustrojowe w Polsce, które rozpoczęto w 1989 r. spowodowały rozwój nowych stacji. W małym zakresie dotyczyło to telewizji katolickiej.

Pozytywnym przykładem w tym zakresie była inicjatywa franciszkanów. W 1994 r. założyli oni stację TV Niepokalanów ${ }^{25}$, regularnie nadająca od 1995 r. Jednak jej zasięg był lokalny. Mimo stosunkowo niewielkich środków stacja skupiała się na funkcjach edukacyjnych, wychowawczych i ewangelizacyjnych, odmiennie niż telewizja publiczna i nadawcy komercyjni. W 2001 r. wystartowała Telewizja Plus, w ramach której istniał kanał religijny Niepokalanów II (kontynuacja TV Niepokalanów). Kanał ten był adresowany do ludzi religijnych oraz poszukujących duchowości, z transmisją Mszy św. i uroczystości religijnych, informacjami z życia Kościoła, komentarzami, wywiadami i dyskusjami. Z przyczyn technicznych Niepokalanów II

celebracji liturgii, 05.12.1994, w: Fotografowanie i filmowanie w służbie ewangelizacji, red. J. Zimny, Sandomierz 2003, s. 63-66.

${ }^{22}$ Por. Instrukcja KEP 2005, nr 15.

${ }^{23}$ Por. tamże, nr 19. 21.

${ }^{24}$ Por. A. Baczyński, Telewizja $w$ duszpasterstwie, w: Media w duszpasterstwie, red. M. Przybysz, T. Wielebski, Warszawa 2014, s. 410-416.

${ }^{25}$ Por. G. Łęcicki, Kościół w eterze, dz. cyt., s. 112-113. 
nie docierał jednak do szerokiego odbiorcy ${ }^{26}$. Franciszkanie byli od 2004 r. częściowymi udziałowcami „TV Plus”. Kolejne przemiany tej telewizji oraz zmiany właścicieli spowodowały to, że w lutym $2010 \mathrm{r}$. franciszkanie odsprzedali jednak swe udziały i wycofali się z tego medium $^{27}$.

Jeśli nie liczyć Redakcji Programów Katolickich w publicznej telewizji, to jedynym wciąż aktualnym i najpełniejszym przykładem katolickiej obecności w świecie telewizji jest „Telewizja Trwam”28, nadająca od 10 czerwca 2003 r. Związana jest ona z Fundacją „Lux Veritatis” i ojcami redemptorystami, podobnie jak „Radio Maryja” i pismo codzienne „Nasz Dziennik”. Telewizyjny przekaz religijny i informacyjny połączony jest z promocją wartości patriotycznych. Liczne transmisje z wydarzeń religijnych dopełnia formacja do postaw płynących z wiary oraz katecheza. Obok dzienników informacyjnych w ramówce stacji znajdują się filmy fabularne i dokumentalne, reportaże czy „Rozmowy niedokończone”. Ten ostatni program skupia się wokół bieżących zagadnień m.in. społecznych, z udziałem ekspertów, a także posiada cechy interaktywności, tj. obejmuje współudział odbiorców, kontaktujących się na bieżąco z prowadzącymi program.

Utrzymanie stacji przede wszystkim opiera się na ofiarności telewidzów oraz innych wiernych. Sporadycznie emituje ona reklamy, z wykluczeniem reklam nieetycznych; dopuszcza także sponsoring programów i lokowanie produktów ${ }^{29}$. Telewizję można oglądać dzięki tradycyjnemu naziemnemu nadawaniu sygnału, jak również w licznych sieciach kablowych, w przekazie satelitarnym (Europa i Ameryka Północna) oraz internetowym (www.tv-trwam.pl). Zwiększenie zasięgu dokonało się przez umieszczenie TV Trwam na tzw.

\footnotetext{
${ }^{26}$ Por. A. BACzyński, Telewizja w duszpasterstwie, dz. cyt., s. 416-418.

${ }^{27}$ Por. http://film.wp.pl/id,105938,title,Franciszkanie-wycofali-sie-z-Telewizji-Puls,wiadomosc.html?ticaid=laac9 (dostęp: 31.10.2016).

${ }^{28}$ Por. http://www.tv-trwam.pl/ (dostęp: 03.11.2016); G. ŁęCICKI, Kościół w eterze, dz. cyt., s. 113; A. BACzyński, Telewizja w duszpasterstwie, dz. cyt., s. 418.

${ }^{29}$ Por. http://tv-trwam.pl/strona/reklama (dostęp: 03.11.2016).
} 
multipleksie telewizyjnym MUX-1 ${ }^{30}$. Chodzi o nadawanie telewizyjne w wersji cyfrowej, kiedy w ramach pasma jednego kanału analogowego dokonuje się przekaz kilku programów cyfrowych (multipleks telewizyjny) ${ }^{31}$. To ostatnie rozwiązanie (od 15 lutego 2014r.) pozwala na dotarcie do $99,5 \%$ populacji Polski.

Mimo znaczącej roli TV Trwam wydaje się, że trudno mówić w ogólności o doniosłej obecności katolickiej telewizji w polskiej rzeczywistości. Jednocześnie istnieje zapotrzebowanie na tematyczne kanały religijne. Świadczy o tym zainteresowanie telewizją Trwam, ale również fakt zaistnienia kanału „Religia.tv”. Ten ostatni przykład - choć niekatolickiej telewizji - wpisuje się w działania stacji komercyjnych, które uruchamiają szereg kanałów tematycznych, jeden $\mathrm{z}$ nich może być poświęcony tematyce religijnej. Telewizja tzw. nowej generacji „n” w ramach platformy cyfrowej grupy ITI nadawała "Religia.tv” (od października 2007 do 31 stycznia 2015). $\mathrm{W}$ tych ramach prezentowano programy z obszaru szeroko pojętej wiary i różnorakich religii. „Religia.tv” oferowała autorskie programy dokumentalne (np. „Szaleńcy Pana Boga”), formaty poradnikowe („Akademia rodzinna”), talk showy („Między sklepami”), programy kulturalne („Kruchta kulturalna”), propozycje kulinarne („Anielska kuchnia”) i inne. Wśród propozycji programowych znajdowały się m.in. programy dokumentalne prezentujące religie świata, popularne miejsca pielgrzymek i życie katolików w różnych krajach ${ }^{32}$.

Powyższy przykład wskazuje na zapotrzebowanie na dobrą telewizję o tematyce religijnej, co koresponduje z myślą istniejącą w ramach

\footnotetext{
${ }^{30}$ W 2012 r. Krajowa Rada Radiofonii i Telewizji nie przyznała Telewizji Trwam miejsca na multipleksie, tj. nie udostępniła cyfrowego nadawania sygnału telewizyjnego. Sprawa braku dostępu do platformy cyfrowej wywołała wówczas szereg protestów środowisk katolickich.

${ }^{31}$ Telewizja cyfrowa wraz z nową formą przekazywania sygnału oferuje także: przewodnik po programach, bibliotekę programów (VOD) oraz warunkowy dostęp do kodowanych programów powiązanych z systemami subskrypcji, por. Społeczeństwo informacyjne, red. J. Papińska-Kacperek, Warszawa 2008, s. 192-195.

${ }^{32}$ Por. http://n.pl/oferta/kanaly/pakiety/informacja_i_rozrywka/religiatv.html (dostęp: 16.08.2010); strona już nie istnieje.
} 
Kościoła, że potrzebna jest dobra stacja katolicka. Między innymi abp John Patrick Foley - były przewodniczący Papieskiej Rady ds. Środków Społecznego Przekazu - stwierdził, że służba dobru wspólnemu domaga się podjęcia działań, które będą miały znaczący wpływ na zaistnienie katolickich całodobowych stacji telewizyjnych; tak jak ma to miejsce w niektórych krajach hiszpańsko lub anglojęzycznych ${ }^{33}$.

Osobnym zagadnieniem jest „niesamodzielna” obecność programów katolickich w ramach telewizji publicznej. Podstawą dla ich funkcjonowania i całej Redakcji Programów Katolickich jest umowa podpisana pomiędzy Konferencją Episkopatu Polski a Telewizją Polską ${ }^{34}$. Redakcja przygotowuje szereg cyklicznych programów, takich jak: „Słowo na niedzielę”, „Znaki czasu”, „My Wy Oni”, „Raj”, „Ziarno”, „Orszak Trzech Króli”, reportaże, transmisje liturgiczne. W roku 2016 największym wydarzeniem w Polsce były Światowe Dni Młodzieży i przyjazd Ojca Świętego Franciszka na te Dni, co było szeroko transmitowane w polskiej telewizji. Te i inne wyemitowane programy opracowane przez Redakcję można odtworzyć na stronie internetowej TVP 35 .

\footnotetext{
${ }^{33}$ Por. Bóg w globalnej wiosce. Arcybiskup John Patrick Foley w rozmowie $z$ Ulrichem Bobingerem, tłum. M. Rodkiewicz, Kraków 2002, s. 38-41. Przenikanie się mediów, tj. ich konwergencja, w tym radiowych, telewizyjnych i innych, dotyczy również mediów watykańskich, por BENEDYKT XVI, Dzięki wam wielu ludzi czuje się bliżej Boga i Kościoła. Przemówienie, 18.12.2008, L’Osservatore Romano wyd. pol. 2 (2009), s. 15-16.

${ }^{34}$ Najmocniejszą podstawą prawną jest zapis w Konkordacie z 1993 r., gwarantujący Kościołowi prawo posiadania własnych środków społecznego przekazu i ich użytkowania oraz prawo do emitowania kościelnych programów w publicznej radiofonii i telewizji, przy respektowaniu prawa polskiego, por. Konkordat między Stolicą Apostolską i Rzecząpospolitą Polską z 28 lipca 1993, Dz. U. z 1998 r. Nr 51, poz. 318, art. 20; por także Ustawa z dnia 17 maja 1989 r. o stosunku Państwa do Kościoła katolickiego w Rzeczypospolitej Polskiej, Dz. U. z 1989 r. Nr 29, poz. 154 z późn. zm., art. 48, poz. 1-3.

${ }^{35}$ Do programów prowadzi zakładka „religia”. Por. także A. BACZyŃski, Telewizja $w$ duszpasterstwie, dz. cyt., s. 420-423.
} 


\section{Internetowa telewizja katolicka w Polsce}

Zmiany dotyczące telewizji prowadzą do odmiennego zapisu, przetworzenia, wysłania i odebrania każdego programu w standardzie cyfrowym. Nie chodzi tylko o odejście od analogowego do cyfrowego nadawania. Elektronizacja spowodowała coraz powszechniejszy dostęp do poszczególnych stacji telewizyjnych i wybranych programów za pomocą komunikacji internetowej. Strony www przekazują bieżące informacje, zawierają programy telewizyjne oraz audycje $\mathrm{z}$ różnych dziedzin ${ }^{36}$. Postępuje tzw. konwergencja mediów, tj. łączenie technik i technologii różnych mediów, a w przyszłości proces ten będzie coraz bardziej się pogłębiał. Większe możliwości techniczne procesorów oraz technologie i oprogramowanie pozwalające odtwarzać filmy i inne programy na różnego rodzaju komputerach oraz narzędziach multimedialnych (tablety, smartfony itp.), to wszystko razem umożliwia połączenie urządzeń cyfrowych z telewizorem i Internetem w jednym urządzeniu („odtwarzaczu”) ${ }^{37}$. Na postępujący trend telewizji przekazywanej przez łącza internetowe wskazuje także fakt, że liczba tego typu użytkowników przewyższyła w 2016 r. (Europa Zachodnia)

\footnotetext{
${ }^{36}$ Por. Telewizja Polska, http://religia.tvp.pl/ (dostęp: 03.11.2016); P. ZIAREK, Sprzężenie telewizji i Internetu jako trend $w$ mediach - uwarunkowania, formy współpracy, perspektywy rozwoju, w: Nowe media a media tradycyjne. Prasa, reklama, Internet, red. M. Jeziński, Toruń 2009, s. 277-291; A. Domaszk, Możliwości zastosowania Internetu w misji Kościoła. Studium kanoniczno-teologiczne, Kraków 2013, s. 181-201.

${ }^{37}$ Por. P. Kościelniak, Więcej komputera $w$ telewizorze, Rzeczpospolita, 29 września 2009, s. A 20-21; Słownik wiedzy o mediach, red. E. Chudziński, Bielsko-Biała 2009, s. 58-61; E. Pulcini, Click TV. Come Internet e il Digitale cambieranno la Televisione, Milano 2006; L. Tomassini, Internet@TV. Dalla televisione alla retevisione, Milano 2011; R. K. Logan, Understanding New Media. Extending Marschal McLuhan, New York 2010, s. 192-203. Problematyka przejścia z analogowego nadawania sygnału telewizyjnego na cyfrowy, por. Digitalizacja a rynek mediów w Polsce, red. T. Klimski, J. Niepsuj, Warszawa 2008; J. Hajdasz, Nowe media, stare problemy, Przewodnik Katolicki 46 (2010), s. 46-47; Media nowej generacji, $z$ E. Kindler-Jaworska, ekspertem do spraw telewizji cyfrowej, rozmawia K. Oldakowski SJ, Przegląd Powszechny 2 (2011), s. 58-69; J. Cieśla , Ekran podłączony do sieci, Rzeczpospolita, 10 sierpnia 2011, s. A 13; A. Grasso, M. Scaglioni, Digitale terrestre o satelite, la conquista del telecomando, Vita e Pensiero (2009) 4, s. 113-119.
} 
liczbę abonentów platform cyfrowych ${ }^{38}$. Ponadto nowe możliwości techniczne pozwalają nawet stosunkowo małej grupie pasjonatów zbudować telewizję internetową, bez koncesji, opłat emisyjnych, czy bardzo skomplikowanych urządzeń.

Opisany wyżej przykład telewizji Trwam pokazuje, że istnieje internetowy dostęp do katolickiej stacji. Uruchamiając witrynę TV Trwam, w zakładce „Na żywo”, otwiera się bezpośredni odbiór sygnału telewizyjnego. Możliwe jest ponadto odtworzenie poszczególnych programów (zakładka „Audycje”), wyemitowanych przez tę stację. Należy podkreślić, że TV Trwam była jedną z pierwszych, która uruchomiła tzw. streaming ${ }^{39}$ (dostarczenie w czasie rzeczywistym przekazu cyfrowego poprzez Internet do odbiorcy jako ciągłego syg$\mathrm{nału}^{40}$ ). Jest to najbardziej rozbudowana propozycja ciągłego odbioru katolickiej telewizji (polskojęzycznej).

W dalszej kolejności trzeba zauważyć propozycje niektórych diecezji ukierunkowane na telewizję internetową. Pierwszym przykładem jest Salve TV (www.salvetv.pl) z rozszerzoną nazwą: Chrześcijańska Telewizja Internetowa. Stację założyła Diecezja Warszawsko-Praska. Misją Salve TV jest prezentowanie w dostępie internetowym dobrych i wartościowych programów informacyjnych, rozrywkowych oraz edukacyjnych, które skierowane są przede wszystkim do ludzi młodych.

Salve TV wystartowała w październiku 2015, a pierwszym programem była codzienna relacja na żywo z Synodu Biskupów o rodzinie (z Watykanu), którą obejrzało ponad 70 tys. widzów w Internecie, jak również ponad 1,5 mln we współpracujących ze stacją innych telewizjach ogólnopolskich. Propozycja telewizyjna obejmuje dyskusje prowadzone na żywo, które dotyczą bieżących i ważnych społecznie

\footnotetext{
${ }^{38}$ Por. M. Lemańska, Telewizja coraz bardziej cyfrowa, Rzeczpospolita 19 kwietnia 2016, s. B4.

${ }^{39}$ Por. A. Baczyński, Telewizja $w$ duszpasterstwie, dz. cyt., s. 418.

${ }^{40}$ Możliwe jest także nazwanie zagadnienia jako media strumieniowe, co dotyczy zwłaszcza radia i telewizji internetowej, w wersji na żywo (live) lub na życzenie (on demand=VOD), por. Media strumieniowe, https://pl.wikipedia.org/wiki/Media_strumieniowe (dostęp: 04.11.2016).
} 
tematów, a także programy autorskie i relacje z najważniejszych wydarzeń z życia Diecezji Warszawsko-Praskiej i Kościoła katolickiego w Polsce ${ }^{41}$. Wśród programów znajdują się ponadto świadectwa wiary, poradniki duchowe, programy informacyjne, recenzje wartościowych książek, reportaże historyczne. Jeden z cykli będących świadectwami wiary nosi tytuł „Święty ogień” i przedstawia historie nawrócenia, pogmatwane ludzkie życiorysy oraz historie działania Bożego światła w życiu. Wybrane programy z propozycji Salve TV są udostępniane również przez współpracujące - inne stacje telewizyjne oraz portale internetowe. Kanał jest także skomunikowany z: Facebook, Twitter, You Tube, Instagram. Niektóre wydarzenia, jak transmisje liturgiczne są nadawane na bieżąco, a pozostała znaczna liczba programów jest do odtworzenia (VOD) w wolnym dostępie, bez żadnego logowania.

Z inicjatywy Archidiecezji Wrocławskiej powstała TV RODZINA (www.tvrodzina.pl/). W odpowiedzi na propozycje środowisk katolickich, na początku roku 2010 ksiądz arcybiskup Marian Gołębiewski, ówczesny metropolita wrocławski powołał dekretem (182/2010) z 25 lutego 2010 roku Katolicką Internetową Telewizję Archidiecezji Wrocławskiej („Filmedia.tv”). Wyznaczył zarazem asystenta kościelnego, opiekuna duchowego przedsięwzięcia ks. dr. Cezarego Chwilczyńskiego, dyrektora Radia Rodzina. W pierwotnej prezentacji tego pomysłu autorzy deklarowali: „Nowo powstały Portal jest jedną z form tzw. multimediów katolickich, które znaleźć możemy wśród polskich stron internetowych. Zamierzeniem twórców Portalu jest stworzenie platformy prezentacji inicjatyw związanych z życiem Kościoła Archidiecezji Wrocławskiej, Duszpasterstw, Parafii oraz różnych wydarzeń i treści związanych $\mathrm{z}$ aktywnością instytucji kulturalnych szczególnie z obszaru województwa dolnośląskiego” ${ }^{2}$.

Pierwotna inicjatywa: „Filmedia.tv” zbierała i prezentowała zapisy video, filmy dodawane przez internautów, serwisy informacyjne, galerie fotograficzne, czy pielgrzymkowe nagrania filmowe. Archiwum

\footnotetext{
${ }^{41}$ Por. O Salve TV, http://www.salvetv.pl/o-salve-tv-10555 (dostęp: 4.11.2016).

${ }^{42} \mathrm{O}$ nas, http://www.filmedia.tv/o-nas.html (dostęp: 9.08.2010), wskazana strona już nie istnieje.
} 
filmów przez lata gromadzone było m.in. na taśmach Betacam i VHS. Równocześnie trwały próby i przygotowania do wdrożenia transmisji na żywo oraz wyboru technologii transmisji video i opracowania strony internetowej. Pilotażowa transmisja on-line nastąpiła na przełomie roku 2012/2013. Pierwsze udane transmisje za pomocą łączy internetowych obejmowały codzienne, wieczorne Msze św. z katedry wrocławskiej. Z czasem nastąpiła zmiana nazwy telewizji internetowej na TV RODZINA ${ }^{43}$.

Na aktualnej stronie omawianej telewizji znaleźć można materiały, filmy, reportaże z życia Archidiecezji Wrocławskiej. W programie jest codzienna transmisja na żywo Mszy św. z katedry wrocławskiej oraz okazjonalne transmisje z różnych uroczystości i wydarzeń religijnych. W każdej chwili jest możliwe odtworzenie materiałów archiwalnych (VOD).

W dalszym rozwoju omawianej telewizji w roku 2014 do jej organizatorów dołączyła Fundacja Vide et Crede, która specjalizuje się w ewangelizacji wizualnej (bilbordy, filmy). W powiązaniu z Wrocławską Pieszą Pielgrzymką (Pielgrzymka TV) stacja prowadzi transmisję i relacje na żywo z pielgrzymek do Częstochowy i Trzebnicy. Telewizja posiada też plany uruchomienia profesjonalnego studia nagrań oraz tworzenia programów informacyjnych i społeczno-kulturalnych (wraz z Radiem Rodzina i Fundacją Vide et Crede). Tak, by móc emitować programy w trybie ciągłym. W zamierzeniu twórców TV RODZINA ważne jest czynne uczestniczenie w życiu Archidiecezji Wrocławskiej, telewizyjne relacjonowanie szeregu wydarzeń w poszczególnych parafiach, na Papieskim Wydziale Teologicznym czy we wrocławskim Seminarium Duchownym ${ }^{44}$. Jest to ciekawa inicjatywa, choć jeszcze nie przypomina typowej telewizji, z ciągłym nadawaniem.

\footnotetext{
${ }^{43}$ Nowopowstała strona łączyła w sobie wcześniejsze doświadczenia filmedia.tv, hallelujah.pl\tv oraz Radia Rodzina.

${ }^{44} \mathrm{O}$ nas, http://tvrodzina.pl/index.php?option=com_content\&view=article\&id= 74\&Itemid=649 (dostęp: 4.11.2016).
} 
Pod patronatem Diecezji Koszalińsko-Kołobrzeskiej istnieje telewizja „Dobre Media” ${ }^{45}$. Stacja promuje i przekazuje wydarzenia, takie jak: „Jezus na stadionie”, „Przystanek Jezus”, „Golgota Młodych”, Palotyńskie Spotkanie Młodych, spotkania młodzieży w Skrzatuszu, rekolekcje z ciekawymi kaznodziejami, sympozja, modlitwy i koncerty, spotkania modlitewne i wiele innych. Często są nadawane transmisje na żywo, prowadzone $\mathrm{z}$ zastosowaniem dobrego sprzętu i oprogramowania do transmisji internetowej z możliwością natychmiastowego dodawania własnych filmów, napisów, grafiki i muzyki. Wiele własnych programów znajduje się w zakładce „Archiwum VOD”. Telewizja jest finansowana przez fundację „Dobre Media Nowej Ewangelizacji”, ustanowioną przez Diecezję Koszalińsko-Kołobrzeską aktem notarialnym z dnia 27 stycznia $2012^{46}$.

Jeszcze inną bardzo rozbudowaną propozycją jest Telewizja LUMEN (www.lumentv.pl). Jej zamierzeniem jest budowanie pozytywnego obrazu Kościoła, ukazywanie jego jako żywej wspólnoty, a także służba dziełu ewangelizacji. W ten sposób stacja pragnie przeciwstawiać się tendencyjnie negatywnemu sposobowi prezentowania świata w sposób uproszczony, czy przedstawianiu człowieka, jako hedonistycznego i bezmyślnego konsumenta oraz odbiorcy. Telewizja ta chce być łącznikiem w integracji ruchów, wspólnot, mediów, duszpasterstw, parafii oraz różnych środowisk głoszących Ewangelię we współczesnym świecie ${ }^{47}$.

O zaplecze materialne stacji zabiega Fundacja Lumen. Została ona założona przy akceptacji biskupa Tadeusza Rakoczego (Diecezja Bielsko-Żywiecka). Telewizja Lumen współpracuje z Komisją Duszpasterstwa Konferencji Episkopatu Polski. Fundacja Lumen posiada umowę o stałej współpracy z Zespołem ds. Nowej Ewangelizacji przy Konferencji Episkopatu Polski. Portal strony szeroko informuje o bardzo złożonym osobowym składzie redakcyjnym i technicznym. Zespół opracował liczne: „Komentarze do Ewangelii”, wydania

\footnotetext{
${ }^{45}$ Por. http://dobremedia.org/ (dostęp: 7.11.2016).

${ }^{46}$ Por. http://www.dobremedia.org/index.php/fundacja (dostęp: 7.11.2016).

${ }^{47}$ Por. O nas, http://www.lumentv.pl/o-nas.html (dostęp: 12.11.2016).
} 
„Wiadomości Diecezjalnych”, relacje filmowe z wydarzeń, wywiady, świadectwa, wideokonferencje, filmy dla parafii, oraz materiały dla różnych wspólnot w Internecie, a także programy dla widzów młodszych, młodzieży i dla kobiet.

Połączeniem multimedialnego portalu z propozycją nowoczesnej ewangelizacji jest KSM TV (www.ksmtv.pl). Projekt witryny powstał w roku 2013 z inicjatywy członków Katolickiego Stowarzyszenia Młodzieży Archidiecezji Przemyskiej. Portal zawiera programy informacyjne, odniesienia do wydarzeń diecezjalnych i ogólnopolskich, ludzi i ich pasji, muzyki, zapisów video i inne. Witryna posiada wtyczki do: Facebook, Instagram, Twitter, You Tube.

Pomysł na telewizję może obejmować stosunkowo niewielki obszar: miasta czy parafii. Jednakże rozpowszechniony w Internecie posiada szersze oddziaływanie. Taką jest Katolicka Telewizja SERBINÓW, która jest nadawana w sieciach kablowych miasta Tarnobrzeg oraz na stronie: tv.serbinow.pl. Współtwórcy tej stacji są wolontariuszami (Stowarzyszenie „Katolicka Telewizja Serbinów”), którzy poświęcają swój czas, a przy okazji rozwijają pasje i zainteresowania, poznają nowoczesne technologie realizacji, montażu, przesyłania i emisji programu telewizyjnego. Mobilny zestaw reporterski pozwala im na realizację transmisji na żywo z każdego miejsca objętego zasięgiem sieci. W programie znajdują się transmisje $\mathrm{z}$ wydarzeń o charakterze katolickim i patriotycznym z Parafii Serbinów, miasta i okolic ${ }^{48}$.

Nie wszystkie pomysły są kontynuowane w dłuższym okresie. Jedną z prób zaistnienia internetowej telewizji katolickiej była stacja Emaus (www.emaus.warszawa.pl). Powstała w roku 2005 po śmierci Ojca Świętego Jana Pawła II. Założeniem była promocja dobra poprzez muzykę chrześcijańską, jako inny odpowiednik muzycznej stacji MTV. Propozycja obejmowała m.in. teledyski z najnowocześniejszych nurtów muzycznych, ale także odniesienia do historii i tradycji. A ponadto celem Emaus była ewangelizacja poprzez publikację materiałów filmowych poświęconych niezwykłym ludziom, z kręgów muzyki, kultury i nauki oraz przybliżenie chrześcijaństwa do tych, którzy są

${ }^{48}$ Por. O nas, http://tv.serbinow.pl/o-nas/ (dostęp: 7.11.2016). 
oddaleni od Kościoła. Formuła oparta na zasadzie non profit zakładała, że współtwórcy nie pobierają wynagrodzenia. Niestety ta próba medialna okazała się zbyt trudna i stacja już nie istnieje $\mathrm{e}^{49}$.

Pomysł na internetową familijną telewizję chrześcijańską o nastawieniu muzycznym prezentuje OPOKA.TV. Na samym początku w 2008 r. rozpoczął działalność portal: „Chrześcijańskie Centrum Multimedialne Opoka.tv" ${ }^{50}$, który prezentował program w wersji VOD, aż do 2014 r. Zamierzeniem i misją autorów OPOKA.TV jest ewangelizacja i przekaz wartościowych treści: „głoszenie prawdy o jedynym Zbawicielu Świata - Jezusie Chrystusie za pośrednictwem nowoczesnych treści i środków przekazu. Fundamentem naszej działalności jest poczucie tożsamości chrześcijańskiej oraz służba drugiemu człowiekowi dla wzmocnienia jego ducha"51. Familijna Telewizja Muzyczna OPOKA.TV oferuje przeróżne materiały wideo i spotkania z ciekawymi ludźmi. Młodym artystom-muzykom, w nurcie współczesnej muzyki chrześcijańskiej, stwarza się na tej platformie możliwość wyemitowania własnych kilkuminutowych materiałów filmowych (teledyski-klipy, fragmenty koncertu, wywiad). Portal przedstawia ponadto filmy, teledyski, materiały mp3, audycje, teksty; recenzje, wywiady, artykuły itd. Internauta sam wybiera, co chce oglądać lub słuchać oraz może umieszczać własne materiały filmowe. Internauta może uruchomić bieżący program „na żywo”; skorzystanie z teledysków oraz programów VOD wymaga zalogowania się na portalu. Kanał jest także dostępny z portali: Facebook, Twitter, You Tube.

Internetowe materiały i odniesienia do telewizji, prasy, radia, felietonów nt. mediów katolickich, forum itd., upowszechnia portal „Klub miłośników dobrych mediów”, który istnieje w sieci od $2002 \mathrm{r}^{52}$ Z innych przykładów form zbliżonych do telewizji można zauważyć portal Frondy, który zawiera katalog „Fronda.tv”. Jednakże są to raczej

\footnotetext{
${ }^{49} \mathrm{O}$ stacji Emaus, por. A. BACZyŃsKi, Telewizja $w$ duszpasterstwie, dz. cyt., s. 419; Emaus TV, http://ichtis.info/emaus-tv/1227 (dostęp: 4.11.2016).

${ }^{50}$ Wcześniej, autorzy tego dzieła byli skupieni wokół portalu „Jezus.com.pl”.

${ }^{51}$ O nas, http://opoka.tv/misja-i-ludzie/ (dostęp: 4.11.2016).

${ }^{52}$ Por. http://kmdm.pl/ (dostęp: 7.11.2016).
} 
wybrane filmy video na temat wiary oraz zagadnienia pokrewne ${ }^{53}$. Podobnie portal Katolickiej Agencji Informacyjnej proponuje szereg filmów chrześcijańskich o charakterze dokumentalnym ${ }^{54}$. Także na wielu portalach diecezjalnych są umieszczone różnego rodzaju programy i filmy (VOD). Podobną sytuację prezentuje powszechnie znany kanał You Tube.

Jeszcze innym przykładem specyficznej telewizji internetowej jest „Gloria $t v$ ”. $\mathrm{Z}$. jednej strony programy i opracowania tekstowe oraz zdjęcia są zebrane tematycznie: „Przegląd” (całości), „Filmy video”, „Wiadomości”, „Grafiki”, „Albumy” i „Komentarze”. Z drugiej wydaje się, że kolejno dokładane przez różnych autorów teksty lub filmy nie stanowią uporządkowanego przekazu. Jedną z cech tej witryny jest możność dodawania - po zalogowaniu się ${ }^{56}$ - własnych komentarzy i uwag, czy tzw. lajkowania. Treść licznych opracowań i programów wskazuje, że wielu użytkowników portalu skłania się ku tzw. „Tradycji Kościoła”, tj. bardziej na utożsamianiu się z myślą kościelną sprzed Soboru Watykańskiego $\mathrm{II}^{57}$. Autorzy portalu nie umieścili autoprezentacji i nie wskazują na podmioty zarządzające lub właścicielskie witryny.

W sieci można odnaleźć wiele różnych propozycji multimedialnych. Także są dostępne polskojęzyczne stacje wyraźnie identyfikujące się z innymi, niż katolickie, wyznaniami chrześcijańskimi. Przykładem jest Trinity Broadcasting Network Polska będąca familijnym kanałem o chrześcijańskich wartościach i oferująca film, muzykę, oraz programy dokumentalne ${ }^{58}$. Właścicielem TBN Polska jest fundacja Trinity Broadcasting Network Polska z Gdańska powiązana z Kościołem Chrześcijańskim Słowo Wiary.

\footnotetext{
${ }^{53}$ Por. http://www.fronda.pl/fronda-tv (dostęp: 4.11.2016).

${ }^{54}$ Por. https://ekai.pl/wydarzenia/wideo/ (dostęp: 4.11.2016).

${ }^{55}$ Por. https://gloria.tv/ (dostęp: 7.11.2016).

${ }^{56}$ Regulamin witryny jest napisany w języku angielskim.

${ }^{57} \mathrm{~W}$ podobnym duchu można odnaleźć prywatną inicjatywę: telewizję „ChristusVincit-tv”, por. http://christusvincit-tv.pl/viewpage.php?page_id=1 (dostęp: 7.11.2016).

${ }^{58}$ Por. http://tbnpolska.tv/ (dostęp: 7.11.2016).
} 


\section{Wnioski}

W podsumowaniu można przedstawić następujące wnioski:

a. Normy powszechnego prawa kanonicznego w niewielkim stopniu bezpośrednio nawiązują do zagadnienia telewizji oraz nie odnoszą się do problematyki telewizji internetowej. Głównie chodzi o ogólne polecenie, aby pasterze Kościoła korzystali z tego narzędzia komunikacji, a wierni współpracowali z pasterzami w wymiarze ewangelizacji, podejmowanej za pośrednictwem mediów.

b. Bardziej konkretne zapisy prawne zawierają dokumenty wydane przez Konferencję Episkopatu Polski i poszczególne Kościoły partykularne, m.in. w formie instrukcji.

c. W polskiej rzeczywistości medialnej - tradycyjnie rozumianej telewizji - najbardziej zauważalną jest stacja Trwam oraz programy katolickie w telewizji publicznej. Niestety, nie powstała katolicka telewizja pod kierownictwem Konferencji Episkopatu Polski.

d. Aktualnie zauważa się dynamiczny rozwój różnego rodzaju telewizji internetowych. Najbardziej rozbudowany program i ciągłe nadawanie - tzw. strumieniowe - cechuje Telewizję Trwam. Inne internetowe stacje są zakładane z inicjatywy Kościołów partykularnych, ruchów kościelnych i osób prywatnych. Często transmitują wybrane wydarzenia kościelne. Zwykle nie nadają ciągłego sygnału; charakterystyczny jest szeroki wybór różnorodnych programów do odtworzenia. Niektóre funkcje, np. wprowadzania komentarza czy dodawania programów, są możliwe po zalogowaniu się. Część z tych stacji jest dostępna również na portalach społecznościowych (Facebook, Twitter, You Tube, Instagram itp.).

e. Do przedstawionych stacji internetowych należy przez analogię stosować nauczanie Magisterium Kościoła. Dyskusyjny może być jednak aspekt katolickiego wymiaru niektórych stacji. O ile można założyć, że te zakładane z inicjatywy poszczególnych diecezji są dziełami katolickimi. To w odniesieniu do niektórych prywatnych inicjatyw, czy współtworzonych przez 
ruchy kościelne lub przez grupy wiernych, takie założenie nie jest pewne. Jeśli internetowe stacje telewizyjne chciałyby używać określenia „katolickie”, to powinny wystąpić do biskupa diecezjalnego lub Konferencji Episkopatu o stosowną akceptację. Ze względu na globalny zasięg Internetu, bardziej wskazane jest odniesienie się do Konferencji Episkopatu. Wskazanym byłoby także poproszenie o przydzielenie asystenta kościelnego i jego ustanowienie, zwłaszcza w odniesieniu do tych inicjatyw, które są powiązane z ruchami kościelnymi. A informacja o uznaniu telewizji za katolicką oraz fakt ustanowienia asystenta powinna być dostępna na witrynie stacji.

f. Należy jednocześnie docenić inicjatywę wielu wiernych, którzy wykorzystują możliwości komunikacji elektronicznej przez tworzenie internetowych stacji telewizyjnych. Postulować należy zarazem, by pasterze Kościoła obejmowali wiernych i ich działania pomocą i wskazaniami w tej dziedzinie.

g. Wielkiej spontaniczności w zakresie nowej obecności telewizyjnej, za pośrednictwem Internetu, niestety nie towarzyszy rozwój kanonicznej myśli prawnej. O ile istnieją nieliczne normy dotyczące telewizji, w tradycyjnym jej rozumieniu, to brakuje odpowiednich rozwiązań dotyczących komunikacji internetowej. W przekonaniu autora należy przez analogię stosować aktualne prawo kanoniczne do nowych przestrzeni medialnych.

Podsumowując, coraz liczniejsze inicjatywy tworzenia telewizji internetowych przez grupy, ruchy katolickie i wiernych są jedną ze współczesnych form nowej ewangelizacji. Stanowią one jakby najnowszą postać głoszenia Ewangelii „na dachach globalnej wioski”, tj. świata, w którym żyjemy. 


\section{The Catholic internet television in thought legal-canonical of the Church}

The contemporary television is also available online. More and more television stations broadcast a typical signal of specific wave frequency and, simultaneously, broadcast the whole program lineup or particular shows on the Internet. Together with a classic form of television, there are TV stations developing which are operating online only.

First of all, the article showed the norms of canonical law referring to the issues of television and, especially, Catholic programmes and stations. Second, the Catholic presence in Polish TV stations was outlined. Third, the last part of the article presented the TV presence of different Catholic subjects online (in Polish).

The norms of universal canonical law are to a very small extent directly referring to the issue of television and are not discussing the problems of the Internet television at all. More specific regulations can be found in the documents issued by the Polish Bishops' Conference and particular Churches, among others, in the form of instructions.

In the Polish media reality, the most visible is Trwam station as well as Catholic programs in the public television. Currently, a rapid development of different types of online television can be noticed. The Internet stations are established on the initiative of particular Churches, church movements and private individuals. They often broadcast the selected church events. Usually, there is no continuous signal but a wide selection of different programmes to be played. On the basis of analogy, the presented Internet stations should be subject to the teaching of Magisterium and the norms of canonical law. However, the aspect of a Catholic dimension of some of the stations might be debatable. If the Internet TV stations want to use the "Catholic" word, they should apply to a diocesan bishop for acceptance. What is more, it would be advisable to ask for a church assistant, especially in relation to church movements. And information of recognizing the television as Catholic and appointing a church assistant should be available at the station's website.

To sum up, an increasing number of internet television initiatives of Catholic groups, movements and the faithful constitutes a contemporary form of new evangelization. The initiatives are a form of preaching the Gospel "at the roof of the global village", that is the world we are living in. 
SŁOWA KLUCZOWE: prawo kanoniczne; telewizja; telewizja internetowa; Internet; narzędzia komunikacji

KEY Words: the canon law; the television; the internet television; Internet; tools of the communication

\section{Nota o Autorze:}

ks. Dr hab. Arkadiusz Domaszk SDB, Prof. UKSW - absolwent Uniwersytetu Kard. Stefana Wyszyńskiego w Warszawie, profesor nadzwyczajny na Wydziale Prawa Kanonicznego UKSW w Warszawie, wykładowca w Wyższym Seminarium Duchownym SDB w Krakowie. Zainteresowania naukowe: prawo o posłudze nauczania, mass media a prawo kanoniczne, dobra doczesne Kościoła, prawo wyznaniowe i prawo zakonne. 